\title{
Apakah Dividen Merefleksikan Kualitas Laba?
}

\author{
Reiner Amos Ivan Prayoga ${ }^{* 1}$, Ika Kristianti \\ 12 Universitas Kristen Satya Wacana
}

\author{
A R T I C L E I N F O \\ Article history: \\ Received 01 December \\ 2019 \\ Received in revised form \\ 31 December 2019 \\ Accepted 15 January 2020 \\ Available online 26 \\ February 2020 \\ Kata Kunci: \\ Kualitas laba, dividen, rasio \\ pembayaran dividen \\ Keywords: \\ Earnings quality, dividends, \\ dividend payout ratios
}

\begin{abstract}
A B S T R A K
Penelitian ini bertujuan untuk mengeksplorasi keterkaitan dividen dengan kualitas laba pada perusahaan manufaktur di Indonesia. Studi tentang kualitas laba perusahaan telah dilakukan tetapi masih sedikit yang mencoba untuk terhubung dengan dividen. Penelitian ini mencoba memberikan bukti bahwa dividen memiliki pengaruh terhadap kualitas laba. Populasi penelitian ini adalah 168 perusahaan manufaktur di Indonesia. Laporan keuangan perusahaan untuk periode 2016-2018 digunakan sebagai sampel penelitian ini. Analisis regresi digunakan sebagai teknik analisis data. Hasil penelitian menunjukkan bahwa pembayaran dividen dan rasio pembayaran dividen berpengaruh positif signifikan terhadap kualitas laba.
\end{abstract}

\section{A B S T R A C T}

This study aimed to explore the relationship between dividends and earnings quality in manufacturing companies in Indonesia. Studies of the quality of corporate earnings have been carried out but few have tried to connect with dividends. This study tried to provide evidence that dividends have an influence on earnings quality. The population of this research was 168 manufacturing companies in Indonesia. The company's financial statements for 2016-2018 were used as a sample of this study. Regression analysis used as a data analysis technique. The results showed that dividend payments and dividend payout ratios had a significant positive effect on earnings quality.

\footnotetext{
* Corresponding author.

E-mail addresses: reiner27@gmail.com (Reiner Amos Ivan Prayoga)
} 


\section{Pendahuluan}

Dalam menyalurkan dana investasi bagi calon investor individual maupun badan dapat dilakukan didalam pasar modal. Sehingga pasar modal adalah sebuah tempat untuk melakukan penawaran maupun permintaan surat-surat berharga (Aini, Maslichah, dan Junaidi, 2019). Sebelum melakukan transaksi didalam pasar modal, calon investor diharapkan memiliki pengetahuan yang cukup untuk memilih instrumen investasi agar tidak terjadi hal yang kurang diinginkan kedepannya. Pasar modal dapat berperan penting dalam mendanai aktifitas pengembangan perusahaan maupun pemerintah. Pemerintah dapat melakukan penerbitan obligasi (surat utang) kemudian menjualnya ke publik di pasar modal, dan sebaliknya, perusahaan menjual kepemilikan perusahaan melalui pasar modal sehingga mendapatkan dana untuk melakukan pengembangan usaha (Nasution, 2015).

Modal merupakan komponen penting untuk mendorong output ekonomi, fungsi pasar modal sangat penting dalam berjalannya ekonomi. Viney (2010) menunjukkan bahwa kontribusi utama pasar modal bagi perekonomian adalah (1) sebagai panduan penggunaan modal untuk investasi jangka panjang yang efisien dan mengembangkan investasi tersebut dengan hasil pengembalian ekonomi yang paling tinggi, (2) memberikan akses ke dalam pasar modal itu sendiri dengan likuiditas yang tinggi sehingga investor dapat lebih efisien dalam berbagi dan mengelola risiko, (3) memperoleh dan mengomunikasikan informasi keuangan yang penting sehingga dapat membantu untuk membuat keputusan dalam investasi jangka panjang.

Dividen merupakan pembagian laba dari hasil proses bisnis suatu perusahaan yang dapat didistribusikan dalam bentuk saham maupun kas. Menurut Denis dan Osobov (2008) dividen dapat menjadi sinyal bagi pemegang saham sebagai indikasi masa depan perusahaan, semakin meningkat nilai dividen yang dibagikan tiap tahun maka diharapkan semakin besar juga peningkatan laba perusahaan. Namun sebaliknya, jika dividen tidak dibagikan atau ditunda, maka dapat menurunkan nilai pasar saham maupun penilaian investor terhadap perusahaan tersebut.

Model signaling dividen tradisional memberikan suatu prediksi bahwa penurunan nilai dividen dapat berpengaruh terhadap masa depan perusahaan Connelly et al., (2011). Sehingga, peningkatan atau penurunan pada dividen yang dibagikan dapat menunjukkan sinyal yang baik maupun sebaliknya terhadap laba yang dihasilkan oleh perusahaan pada masa yang akan datang (Bhargava, 2018; Shapiro dan Zhuang, 2015). Namun ada beberapa hasil penelitian yang bertentangan terhadap hal tersebut yang menyatakan bahwa informasi yang didapatkan dari dividen dinilai lemah (Brav et al., 2005; DeAngelo, DeAngelo, dan Stulz, 2006).

Penelitian Anita dan Fitriani (2015); Deng, Li, dan Liao (2017) menyatakan bahwa laba pada perusahaan tidak hanya dapat dipengaruhi oleh status pembayaran dividen dan kenaikan jumlah dividen saja, namun juga dapat dipengaruhi oleh persistensi dividen. Akan tetapi tidak ditemukan bahwa besarnya nilai dividen yang dibagikan akan berpengaruh terhadap kualitas laba. Penelitian ini juga selaras terhadap hasil penelitian He et al., (2016) bahwa pembayaran dividen dapat menarik perhatian analisis, mendapatkan reaksi positif dari pasar saham, serta dapat mempertahankan nilai dagang saham suatu perusahaan pada pasar saham.

Laba yang diukur berdasarkan basis akrual akuntansi dianggap sebagai ukuran ringkasan kinerja perusahaan oleh beragam pengguna (Dechow, 1994). Pemegang saham dan investor menggunakan hal tersebut untuk mengukur kinerja suatu perusahaan. Pengukuran laba juga banyak digunakan sebagai dasar untuk mengevaluasi serta memberikan penghargaan kepada manajer perusahaan (Kowerski, 2013). Kualitas laba dapat dipahami dan diukur secara berbeda karena tidak ada definisi yang tepat dan dapat dinilai melalui berbagai teknik pengukuran (Abdelghany, 2005). Menurut Dechow, Ge, dan Schrand (2010), kualitas laba dapat didefinisikan sebagai "Pendapatan yang berkualitas tinggi memberikan lebih banyak informasi mengenai kinerja keuangan perusahaan yang relevan dengan keputusan khusus yang dibuat oleh manajer ". Dechow dan Schrand (2004) menggambarkan bahwa tingginya angka laba dapat diartikan sebagai laba tersebut memiliki kualitas yang tinggi dan secara tepat mencerminkan bagaimana kinerja operasional perusahaan saat ini, serta berfungsi sebagai ukuran yang baik untuk kinerja operasi masa depan dan merupakan ringkasan pengukuran yang bermanfaat untuk memperkirakan nilai perusahaan.

Kualitas laba pada umumnya menjadi masalah penting bagi pengambilan keputusan, terlebih jika dikaitkan dengan adanya tujuan kontrak tertentu dan investasi (Francis, Olsson, dan Schipper, 2006). Informasi laba yang dilaporkan oleh manajemen akan digunakan pemangku kepetingingan dalam pengambilan keputusan investasi dana maupun prediksi laba dimasa yang akan datang (Novianti, 2012). Semakin baik kualitas laba yang dihasilkan maka akan menjadi sebuah keuntungan bagi perusahaan dan juga manajer perusahaan tersebut (Puspita, 2019). Berbanding terbalik, jika kualitas laba yang dihasilkan 
tidak sesuai dengan realitas ekonomi maka akan menyebabkan kerugian bagi para pemangku kepentingan.

Penilaian pada kualitas laba adalah hal yang dipertimbangkan investor dalam melakukan investasi (Untung dan Hanna, 2017). Jika dividen perusahaan dibagikan dengan tingkat yang tinggi maka akan dianggap perusahaan memiliki kualitas laba yang baik. Namun sebaliknya, jika dividen yang dibagikan tingkatnya rendah maka akan dianggap bahwa kualitas laba perusahaan rendah. Hal tersebut didasari oleh 2 alasan, alasan pertama yaitu teori keagenan, dimana dapat mengurangi masalah keagenan. Dividen dapat mengurangi masalah biaya keagenan karena dapat mencegah kinerja dan aktifitas manajer dari mengubah pendapatan yang ada dalam laporan keuangan yang telah dipantau oleh pasar modal (Easterbrook, 1984). Mencegah manajer dalam melakukan kecurangan pada arus kas dirasa sulit, walaupun informasi aset perusahaan dapat diakses oleh pemegang saham, maka dari itu dividen yang dibayarkan oleh manajemen kepada pemegang saham harus selalu cukup (Myers, 2000).

Alasan kedua yaitu, dividen yang dibagikan dalam bentuk kas merupakan aktivitas yang dapat meningkatkan arus kas dan tidak dapat mencerminkan kinerja perusahaan. Dividen belum tentu dapat membantu perusahaan dalam mengembangkan aktivitas bisnisnya. Oleh karena itu, aktivitas pembagian dividen adalah hal yang mahal bagi perusahaan (Tong dan Miao, 2011). Namun, dengan adanya dividen dirasa dapat mengurangi kecurigaan terhadap manipulasi laba pada perusahaan (Glassman, 2005). Hal tersebut juga didukung oleh penelitian (Easterbrook, 1984), bahwa perusahaan memiliki kemungkinan kecil dalam memanipulasi laba jika perusahaan membagikan dividen dikarenakan jumlah laba akan berpengaruh terhadap tingkat dividen yang diterima oleh pemegang saham.

Hasil analisis lebih lanjut oleh Deng et al., (2017) ditemukan bahwa hubungan antara dividen dengan kualitas laba dapat dipengaruhi oleh faktor-faktor yang mempengaruhi insentif terhadap pembayaran dividen. Ditemukan bahwa dampak positif dari dividen terhadap kualitas laba berkurang kepada perusahaan yang melakukan refinancing ekuitas, kemudian kepemilikan negara terhadap suatu perusahaan juga dapat menurunkan informasi dari dividen tersebut. Penelitian Untung dan Hanna (2017) menunjukkan bahwa status pembayaran dividen dan rasio pembayaran dividen tidak berkaitan dengan kualitas laba serta tidak ditemukan juga bukti keterkaitan antara dividen dan kualitas laba suatu perusahaan.

Penelitian ini bertujuan untuk menganalisis dan menemukan bukti empiris bahwa dividen memiliki keterkaitan terhadap kualitas laba suatu perusahaan. Penelitian ini diharapkan dapat menambah pengetahuan mengenai keterkaitan dividen terhadap kualitas laba perusahaan, serta bermanfaat bagi penelitian berikutnya.

\section{Metode}

Penelitian ini memiliki populasi yang terdiri dari 168 perusahaan manufaktur terdaftar di Bursa Efek Indonesia selama periode 2016-2018 (tiga tahun). Data di penelitian ini menggunakan cross sectional dan time series dan didapat dengan metode purposive sampling. Dalam penentuan sampel, kriteria yang diterapkan yaitu perusahaan yang memiliki laporan keuangan dari tahun 2016-2018 (tiga tahun), perusahaan laba (tidak rugi), dan perusahaan go-public. Sehingga didapatkan sampel total pengamatan.

Dalam model Dechow et al., (1995), koefisien dalam menguji hipotesis adalah pembayaran dividen, maka dari itu variabelnya adalah status pembayaran dividen dan rasio pembayaran dividen. Keterangan:

a. Status Pembayaran Dividen = nilai 1 jika membagikan dividen, nilai 0 jika sebaliknya

b. Rasio pembayaran dividen = nilai 1 jika rasio diatas 0,25 , dan 0 jika sebaliknya.

Penggabungan data time series dan cross-sectional yang memiliki karakteristik dari data panel dilakukan dalam penelitian ini untuk menguji pengaruh pembagian dividen dengan kualitas laba selama tahun 2016 hingga tahun 2018. Analisis estimasi koefisien untuk model ini menggunakan model regresi linier berganda SPSS versi 26.0. Hasil pengumpulan data kemudian diinterpretasikan dan dianalisis dengan bentuk yang digunakan dalam diskusi. Sebelum menguji hipotesis, uji asumsi klasik telah dilakukan yang meliputi uji multikolinieritas, uji autokorelasi, uji normalitas, dan uji heteroskedastisitas.

\section{Hasil dan pembahasan}

Statistik deskriptif digambarkan dengan nilai minimal, nilai maksimal, mean, dan standar deviasi dari semua variabel: 
Tabel 1. Hasil Statistik Deskriptif

\begin{tabular}{llllll}
\hline & $\mathrm{N}$ & Minimum & Maximum & Mean & Std. Deviation \\
\hline Earnings_Quality & 249 & 0,0000 & 0,6690 & 0,043309 & 0,1038569 \\
DPS & 249 & 0,00 & 1,00 & 0,7912 & 0,40730 \\
DPR & 249 & 0,00 & 1,00 & 0,5020 & 0,50100 \\
Size & 249 & 25,22 & 33,47 & 28,7676 & 1,63668 \\
ROA & 249 & 0,08 & 2,06 & 0,4500 & 0,24884 \\
LEV & 249 & 0,00 & 0,92 & 0,0816 & 0,09627 \\
AGE & 249 & 0,00 & 37,00 & 20,6506 & 9,92565 \\
Valid N (listwise) & 249 & & & & \\
\hline
\end{tabular}

Sumber: SPSS 26.0, diproses oleh penulis, 2020

Berdasarkan tabel 1 diatas, kolom N menjelaskan 249 data yang sah digunakan pada penelitian ini. Earnings Quality (Y) sebagai variable dependen yang mempunyai nilai minimal 0 adalah Primarindo Asia Infrastructure Tbk (BIMA) selama tahun 2016 dan nilai maksimal 0,669 adalah PT Barito Pacific Tbk (BRPT) selama tahun 2018. Nilai mean dan standar deviasi dari nilai akrual diskresioner yaitu 0,43309 dan 0,1038569. Variabel independen DPS (X1) yang diukur menggunakan variabel dummy punya nilai minimal 0 dan nilai maksimal 1. Variabel DPS punya nilai mean 0,7912 dan nilai standar deviasi 0,40730. Variabel independen yang kedua DPR (X2) yang juga diukur menggunakan variabel dummy punya nilai minimal 0,00 dan nilai maksimal 1,00. Nilai mean dari DPR 0,5020 dan nilai standar deviasinya 0,50100. Variabel Size (X3), ROA (X4), LEV (X5) dan AGE (X6) adalah variabel kontrol.

Setelah uji asumsi klasik yang berisi uji multikolinieritas, uji heteroskedastisitas, uji autokorelasi dan uji normalitas telah dilakukan, kemudian langkah selanjutnya yaitu menguji hipotesis. Selanjutnya, hasil dari uji asumsi klasik menunjukkan bahwa model regresi didalam penelitian ini layak untuk digunakan dalam pengujian hipotesis.

Pengujian hipotesis pada penelitian ini menggunakan metode analisis regresi linear berganda dimana untuk menentukan apakah variabel independen yaitu DPS (Status Pembayaran Dividen), DPR (Rasio Pembayaran Dividen), ukuran perusahaan (Size), Return on Asset (ROA), Leverage (LEV), dan umur perusahaan $(A G E)$ berpengaruh terhadap variabel dependen yaitu kualitas laba (Earnings Quality).

Berdasarkan tabel 2 dibawah ini, nilai signifikan dari F yaitu 0,00 dimana nilai tersebut dibawah 0,05 . Maka jika nilai level signifikan berada dibawah 0,05 , model regresi dapat memprediksi variabel dependen (kualitas laba) dan dapat dipengaruhi oleh DPS (Status Pembayaran Dividen), DPR (Rasio Pembayaran Dividen), ukuran perusahaan (Size), Return on Asset (ROA), Leverage (LEV), dan umur perusahaan $(A G E)$.

Tabel 2. Hasil Uji Statistik F

\begin{tabular}{llrrrrr}
\hline & & \multicolumn{2}{c}{ Sum of } & \multicolumn{2}{c}{ Mean } & Sig. \\
\hline 1 & Squares & df & Square & F & $.000^{\text {b }}$ \\
& Regression & 1,118 & 6 & 0,186 & 28,942 & \\
& Residual & 1,557 & 242 & 0,006 & & \\
& Total & 2,675 & 248 & & & \\
\hline
\end{tabular}

Sumber: SPSS 26.0 Output, 2020

Dari tabel 2 diatas, hasilnya juga menunjukkan bahwa model regresinya tepat dan dapat diproses menggunakan uji T.

Penggunaan Uji Adjusted R-Square atau uji koefisien determinasi yaitu, untuk mengukur seberapa baik model tersebut dapat mendeskripsikan variasi dari variabel dependen. Sama dengan koefisien korelasi, nilainya antara 0 sampai 1. Jika nilai dari Adjusted $R$-Square mendekati 1 maka variabel independen dapat memprediksi variasi dari variabel dependen, sedangkan jika nilainya mendekati 0 maka kemampuan dalam memprediksi sangat kecil atau tidak mungkin.

Tabel 3. Hasil Uji Adjusted R-Square

\begin{tabular}{lllll}
\hline Model & R & R Square & Adjusted R Square & Std. Error of the Estimate \\
\hline 1 & $.646^{\mathrm{a}}$ & 0,418 & 0,403 & 0,0802224 \\
\hline
\end{tabular}

Sumber: SPSS 26.0 Output, 2020 
Berdasarkan dari Tabel 3 diatas, nilai dari Adjusted R-Square adalah 0,403. Hasil ini mengindikasikan bahwa 40,3\% variasi dari kualitas laba dapat dijelaskan oleh variasi dari variable independen yaitu DPS (Status Pembayaran Dividen), DPR (Rasio Pembayaran Dividen), ukuran perusahaan (Size), Return on Asset (ROA), Leverage (LEV), dan umur perusahaan (AGE). Sedangkan sisanya 59,7\% dijelaskan oleh faktor-faktor diluar model.

Tabel 4. Hasil Uji Statistik T

\begin{tabular}{|c|c|c|c|c|c|c|}
\hline Model & & & & $\begin{array}{l}\text { dized } \\
\text { ents }\end{array}$ & $\mathrm{t}$ & Sig. \\
\hline \multirow[t]{7}{*}{1} & (Constant) & $-1,153$ & 0,092 & & $-12,552$ & 0,036 \\
\hline & DPS & $-0,016$ & 0,015 & $-0,064$ & $-1,065$ & 0,288 \\
\hline & DPR & $-0,006$ & 0,012 & $-0,029$ & $-0,488$ & 0,626 \\
\hline & Size & 0,041 & 0,003 & 0,650 & 12,623 & 0,075 \\
\hline & ROA & 0,035 & 0,022 & 0,084 & 1,604 & 0,110 \\
\hline & LEV & 0,019 & 0,058 & 0,017 & 0,321 & 0,749 \\
\hline & AGE & 0,000 & 0,001 & 0,038 & 0,738 & 0,461 \\
\hline
\end{tabular}

Hipotesis pertama (H1) yang dikembangkan dalam penelitian ini adalah kualitas laba perusahaan dipengaruhi oleh pembayaran dividen. Berdasarkan tabel 4, nilai signifikan status pembayaran dividen (DPS) adalah 0,288. Nilai tersebut diatas 0,05, maka status pembayaran dividen (DPS) memiliki pengaruh signifikan terhadap kualitas laba, yang berarti bahwa hipotesis pertama diterima dan perusahaan yang membagikan dividen akan memiliki kualitas laba yang lebih baik dibandingkan perusahaan yang tidak membagikan dividennya. Dari analisis hipotesis diatas, hasilnya berbeda dengan penelitian sebelumnya oleh Untung dan Hanna (2017) namun sesuai dengan hasil penelitian oleh Sirait dan Siregar (2014); Skinner dan Soltes (2011); Tong dan Miao (2011), bahwa kualitas laba yang baik dimiliki oleh perusahaan yang membagikan dividen. Hal ini mungkin disebabkan oleh pengaruh variabel lainnya yang tidak masuk di dalam model penelitian dan juga faktor-faktor lain seperti peluang pertumbuhan laba perusahaan pada jangka panjang yang diteliti oleh Widayanti, Vestari, dan Farida (2014) bahwa pertumbuhan laba yang baik dan signifikan pada perusahaan memiliki nilai yang tinggi pada Koefisien Respons Laba (ERC) sehingga berpengaruh terhadap kualitas laba.

Hipotesis kedua (H2) yang dikembangkan pada penelitian ini yaitu kualitas laba tinggi dipengaruhi oleh perusahaan yang memiliki rasio pembayaran dividen yang besar. Berdasarkan tabel 4, nilai signifikan dari rasio pembayaran dividen (DPR) adalah 0,626, dimana nilai tersebut diatas 0,05. Sehingga rasio pembayaran dividen (DPR) berpengaruh signifikan terhadap kualitas laba, yang berarti bahwa hipotesis kedua diterima dan perusahaan yang memiliki rasio pembayaran dividen tinggi memiliki kualitas laba yang tinggi.

Dari analisis tersebut, hasilnya sesuai dengan hasil penelitian Tong dan Miao (2011) dimana kualitas laba yang tinggi didapatkan dengan rasio pembayaran dividen yang tinggi. Akan tetapi, hal ini tidak sesuai dengan penelitian Sirait dan Siregar (2014); Skinner dan Soltes (2011); Untung dan Hanna (2017) bahwa perusahaan dengan rasio pembayaran dividen tinggi memiliki kualitas laba yang rendah. Untung dan Hanna (2017) menyatakan bahwa faktor yang dapat mempengaruhi hasil penelitian mereka adalah data perusahaan manufaktur di Indonesia yang diteliti sebanyak 37,1\% merupakan perusahaan yang membayar dividen besar sedangkan sisanya sebesar 62,9\% merupakan perusahaan yang membayar dividen kecil. Namun sebaliknya, data yang ada pada penelitian ini mayoritas adalah perusahaan dengan pembayaran dividen besar sebesar $79,1 \%$ dan sisanya merupakan perusahaan yang membayar dividen kecil sebesar 20,9\%. Maka dari hasil tersebut ukuran dividen merupakan faktor signifikan yang mempengaruhi kualitas laba perusahaan.

\section{Simpulan dan saran}

Berdasarkan analisis hasil penelitian diatas dapat disimpulkan bahwa indikator-indikator dividen seperti status pembayaran dividen (DPS) dan rasio pembayaran dividen (DPR) berpengaruh signifikan terhadap kualitas laba. Ukuran dividen menjadi faktor yang berpengaruh terhadap kualitas laba, hal tersebut dibuktikan dengan penelitian sebelumnya oleh Untung dan Hanna (2017) yang mayoritas sampelnya adalah perusahaan dengan pembayaran dividen rendah sebesar 62,9\% dan sisanya merupakan perusahaan dengan pembayaran dividen yang tinggi sebesar 37,1\%. Namun sebaliknya, pada 
penelitian ini mayoritas sampel yang tinggi adalah perusahaan yang membayar dividen bernilai tinggi sebesar $79,1 \%$ dan sisanya $20,9 \%$ merupakan perusahaan dengan pembayaran dividen yang bernilai rendah. Sehingga, yang mempengaruhi kualitas laba suatu perusahaan adalah ukuran dari jumlah pembayaran dividen.

\section{Daftar Rujukan}

Achmad, T. (2012). Dewan Komisaris Dan Transparansi: Teori Keagenan Atau Teori Stewardship? Jurnal Keuangan Dan Perbankan, 16(1), 1-12.

Aini, N., Maslichah, \& Junaidi. (2019). Pengaruh Pengetahuan Dan Pemahaman Investasi, Modal Minimum Investasi, Return, Risiko Dan Motivasi Investasi Terhadap Minat Mahasiswa Berinvestasi Di Pasar Modal (Studi Pada Mahasiswa Fakultas Ekonomi Dan Bisnis Kota Malang). E-JRA Vol. 08 No. 05 Agustus 2019 Fakultas Ekonomi Dan Bisnis Universitas Islam Malang, 08(05), 38-52.

Anita, D., \& Fitriani, N. (2015). Pengaruh Pembayaran Dividen Terhadap Kualitas Laba. Pengaruh Pembayaran Dividen Terhadap Kualitas Laba, 4(2), 64-75.

Bhargava, S. (2018). Theory of Signalling Dividends: An Economic Analysis. Retrieved from https://ssrn.com/abstract=3233042

Brav, A., Graham, J. R., Harvey, C. R., \& Michaely, R. (2005). Payout policy in the 21st century. Journal of Financial Economics, 77(3), 483-527. https://doi.org/10.1016/j.jfineco.2004.07.004

Connelly, B. L., Certo, S. T., Ireland, R. D., \& Reutzel, C. R. (2011). Signaling theory: A review and assessment. Journal of Management, 37(1), 39-67. https://doi.org/10.1177/0149206310388419

DeAngelo, H., DeAngelo, L., \& Stulz, R. M. (2006). Dividend policy and the earned/contributed capital mix: a test of the life-cycle theory. Journal of Financial Economics, 81(2), 227-254. https://doi.org/10.1016/j.jfineco.2005.07.005

Dechow, M. (1994). Accounting \& Economics The role of accounting accruals. Journal of Accounting and Economics, 18, 3-42. https://doi.org/10.1016/0165-4101(94)90016-7

Dechow, P. M., \& Dichev, I. D. (2002). The quality of accruals and earnings: The role of accrual estimation errors. Accounting Review, 77(SUPPL.), 35-59. https://doi.org/10.2308/accr.2002.77.s-1.61

Dechow, P. M., \& Schrand, C. M. (2004). Earnings Quality.

Dechow, P. M., Sloan, R. G., \& Sweeney, A. P. (1995). Detecting Earnings Management. The Accounting Review, 70(2), 193-225. Retrieved from http://www.jstor.org/stable/248303

Easterbrook, F. H. (1984). Two Agency-Cost Explanations of Dividends. The American Economic Review, 74(4), 650-659. Retrieved from http://www.jstor.org/stable/1805130

Francis, J., Olsson, P., \& Schipper, K. (2006). Earnings quality. Foundations and Trends in Accounting, 1(4), 259-340. https://doi.org/10.1561/1400000004

Glassman, J. (2005). When numbers don't add up. Kiplinger's Personal Finance, 59(8), 32-34.

Halim, A., \& Abdullah, S. (2006). Hubungan Masalah Keagenan Di Pemerintah Daerah: Sebuah Peluang Penelitian Anggaran dan Akuntansi. Jurnal Akuntansi Pemerintahan, 2(1), 53-64.

He, X., Li, M., Shi, J., \& Twite, G. (2016). Why do firms pay stock dividends: Is it just a stock split? Australian Journal of Management, 41(3), 508-537. https://doi.org/10.1177/0312896214553858

Keagenan Pada Kinerja Keuangan Daerah Dan Belanja Modal (Studi Pada Provinsi Di Indonesia). Jrak. Vol. 7 No. !, 7(1), 11-21. 
Kothari, S. P., Leone, A. J., \& Wasley, C. E. (2005). Performance matched discretionary accrual measures. $\begin{array}{llll}\text { Journal of Accounting and } & \text { Economics, }\end{array}$ https://doi.org/10.1016/j.jacceco.2004.11.002

Kowerski, M. (2013). Dividends and earnings quality in poland.

McNichols, M. F. (2002). Discussion of the Quality of Accruals and Earnings: The Role of Accrual Estimation Errors. Accounting Review, 77(SUPPL.), 35-59. https://doi.org/10.2308/accr.2002.77.s1.61

Myers, S. C. (2000). Outside Equity Financing. Journal of Finance, 55(3), 1005-1037. Retrieved from https://onlinelibrary.wiley.com/doi/epdf/10.1111/0022-1082.00239

Nasution, Y. S. J. (2015). Peranan Pasar Modal Dalam Perekonomian Negara. Peranan Pasar Modal Dalam Perekonomian Negara, 2(1), 95-112.

Novianti, R. (2012). Kajian Kualitas Laba Pada Perusahaan Manufaktur Yang Terdaftar Di Bei. Accounting Analysis Journal, 1(2), 1-6. https://doi.org/10.15294/aaj.v1i2.656

Pratiwi, R., \& Yulianto, A. (2016). Pengaruh Struktur Kepemilikan dan Komisaris Independen terhadap Biaya Keagenan Perusahaan yang Masuk dalam Indonesia Most Trusted Companies. Management Analysis Journal, 5(3), 215-228. https://doi.org/10.15294/maj.v5i3.11119

Puspita, I. \& H. L. (2019). KUALITAS LABA. 8(2003), 1-9.

Shapiro, D., \& Zhuang, A. (2015). Dividends as a signaling device and the disappearing dividend puzzle. $\begin{array}{lllll}\text { Journal of Economics and } & \text { Business, }\end{array}$ https://doi.org/10.1016/j.jeconbus.2014.12.005

Skinner, D. J., \& Soltes, E. (2011). What do dividends tell us about earnings quality? Review of Accounting Studies, 16(1), 1-28. https://doi.org/10.1007/s11142-009-9113-8

Untung, A., \& Hanna. (2017). the Relationship Between Dividend Payment Patterns. 12(2), 1-16. https://doi.org/10.1108/S0196-382120170000033003

Viney, C. (2010). Financial market essentials. McGraw-Hill Education Australia.

Widayanti, C. A., Vestari, M., \& Farida, D. N. (2014). Faktor-faktor yang mempengaruhi kualitas laba pada perusahaan high profile yang terdaftar di BEI. Jurnal Dinamika Ekonomi \& Bisnis, 11, 46-64. https://doi.org/10.1017/S0266467408005026 